\title{
Dutiful citizen or a pragmatic professional? Voluntary retirement of Icelandic local councillors
}

\author{
Eva Marín Hlynsdóttir, Assistant Professor, Faculty of Political Science, \\ University of Iceland.
}

\begin{abstract}
This article explores the working conditions of Icelandic local councillors in relation to voluntary retirement from the council. In the past three elections, the turnover in councils has been very high, with approximately six out of every 10 council members being new recruits at the beginning of each term. The turnover has also highlighted possible gender issues, as more women than men (proportionally) leave the council after their first term. The findings reveal a significant difference between the councillors who plan to stay and those who opt to leave. This is in relation to the local authorities' population size, satisfaction with remuneration, and seniority in the council. Thus, councillors in larger municipalities or councillors satisfied with their remuneration are more likely to run for council versus councillors from smaller municipalities and those less happy with their remuneration. Seniority is also a decisive factor, as the majority of all councillors leave after the first term. Significant differences were not found between the female and male councillors in relation to voluntary retirement. However, gendered differences were found in relation to institutional position and working conditions, suggesting a gender-based division of labour in local councils.
\end{abstract}

Keywords: Voluntary retirement; local councillors; gender; population size.

\author{
Icelandic Review of Politics and Administration Vol. 13, Issue 2 (169-188) \\ (C) 2017 Contact: Eva Marín Hlynsdóttir, evamarin@hi.is \\ Article first published online December 14th 2017 on http://www.irpa.is \\ Publisher: Institute of Public Administration and Politics, Gimli, Sæmundargötu 1, 101 Reykjavík, Iceland \\ Stjórnmál \& stjórnsýsla 2. tbl. 13. árg. 2017 (169-188) Fræđigreinar \\ (C) 2017 Tengiliður: Eva Marín Hlynsdóttir, evamarin@hi.is \\ Vefbirting 14. desember 2017 - Birtist á vefnum http://www.irpa.is \\ Útgefandi: Stofnun stjórnsýslufræđa og stjórnmála, Gimli, Sæmundargötu 1, 101 Reykjavík \\ DOI: https://doi.org/10.13177/irpa.a.2017.13.2.1 \\ This work is licensed under a Creative Commons Attribution 3.0 License.
}




\section{Introduction}

Local authorities have experienced turbulent times during the past several decades. The number of municipalities has dropped 64 percent from 204 in 1990 to 74 in 2017. Consequently, the number of elected members in local councils is now 504, compared to 1116 in 1990 (Statistics Iceland 2017a). During the same period, the responsibilities for local governments have grown substantially as they are now for example responsible for primary education and disability services. In 2014, fulfilment of these responsibilities required a commitment of approximately 30 percent of the total public expenditure, up from 20 percent in the 1990s (Kristinsson 2014). Traditionally, Icelandic local governments have enjoyed high levels of trust, with around 60 percent expressing high confidence in local government in 2009 (Kristinsson 2014). The recent financial turbulence does not seem to have shaken the public's trust.

However, there are some worrying trends at the local level. Traditionally, there is a high turnout for elections at the local level. This trend has been disrupted, as the past three elections displayed notable decline in voter participation. The turnout went below 80 percent to 78.7 percent in 2006. It again dropped to 73.4 percent in 2010 and 66.5 percent in 2014. The turnout in the city of Reykjavík dropped below 60 percent. At the same time, the number of new members in the local council has risen dramatically. In the past three elections, around six of every ten members of local councils are new recruits (Statistics Iceland 2010; 2015).

Furthermore, problems have been reported regarding the recruitment of candidates willing to run for council (Samband íslenskra sveitarfélaga 2013). The impact of recruitment on political careers is a well-known field of research (MacKenzie \& Kousser 2014; Schlesinger 1966), especially within legislative studies. Although research on local councillor recruitment is less developed, there is still some notable work available on the subject (Verhelst, Reynaert, \& Steyvers 2013). The voluntary retirement of local councillors has received even less attention (Aars \& Offerdal 1998; Hjelmar, Olsen, \& Pedersen 2010), although this affects how we view the development of political careers.

Local councillors in Iceland receive their mandate through local elections, and as is the case with national politics, some candidates get elected and some do not. Local politics have proven to be somewhat less turbulent than politics on the national level. Nevertheless, in the past 15 years the number of voluntary retirements from local councils (individuals who do not seek re-election) has risen dramatically. It is foreseeable that at least 40 percent of councillors will not be seeking re-election in the May 2018 local elections.

The aim of this paper is twofold. The first objective is to explore the differences between councillors who express the willingness to run for re-election and those who choose not to run. The second objective is to discuss why the high level of voluntary retirements at the local level may not be good for local governance.

The article begins with an overview of the theoretical background and an introduction of the hypothesis. The second section discusses the Icelandic political system. The third section introduces the data collection, and the results are explained in the fourth section. The paper then closes with a discussion. 


\section{Theoretical framework: From laymen to professional}

Mouritzen and Svara (2002) argue that all local governments present some middle ground between the principles of the 'layman rule', 'political leadership', and 'professionalism'. When applying these principles to the recruitment process of local councillors, two ideal types of recruitment and career development emerge. One type is based on the layman or amateur politician, Steyvers and Verhelst (2012) claim that this type is ideal and is based on the idea of political equality. Essentially, this means that any citizen who meets required criteria like age or citizenship is eligible for political office. Therefore, the recruitment process is open, and movement in and out of the political sphere is relatively simple. Ideally, the council proportionally reflects society. In this case, the emphasis is on the representative role of the councillor (Beetham 1996).

On the other hand, Steyvers and Verhelst (2012) point to the notion of politics as a profession (Borraz \& John 2004; Guérin \& Kerrouche 2008), where chances for recruitment and career development are no longer equally distributed. Thus, there is an overrepresentation of the brokerage professions, such as lawyers or teachers (Norris 1997; Reynaert 2012) in systems based on the professional principle. In this instance expertise matters more than mirroring society, therefore, the importance of responsiveness exceeds representativeness (Beetham 1996).

If we further explore these ideal types, we see that professional politicians are viewed as ambitious individuals who are constantly searching for a way to enhance their political careers (MacKenzie \& Kousser 2014; Schlesinger 1966). However, laymen individuals develop different attitudes since their participation in council work is regarded as a leisure-time activity (Steyvers \& Verhelst 2012), and they do not necessarily see reelection as a goal in and of itself. This contrasts with professional politicians, who try to establish continuity in their careers (Aars \& Offerdal 1998). The debate between laymen and professional politicians also touches on the overall relationship between politics and administration. This relationship explores whether politics and administration should be regarded as separate spheres or overlapping (Demir 2009; Frederickson \& Smith 2003).

Overall, the foundation of local government systems has changed in the past 25 years. Although decentralisation and increased autonomy at the local level has strengthened the control of local councils, the decision-making processes have simultaneously become more complex (Guérin \& Kerrouche 2008). These changes have increased the demand for a higher level of expertise in local councillors, as well as the demand for a greater distribution of power between different types of councillors. Guérin and Kerrouche $(2008,179-180)$ argue that this has increased the gap between regular councillors (backbenchers) and those assigned to leadership positions, this puts a question mark behind the role of council members in the public domain (Lepine \& Sullivan 2010).

The Icelandic council-committee system is principally a layman system, as all councillors except members of the Reykjavík city council are paid part-time for their involvement. Though local authorities are legally obligated to provide remuneration for local councillors, there are no coordinated pay scales or salary benchmarks like those often found in other countries (Guérin \& Kerrouche 2008, 187). The lack of benchmarks 


\section{STJÓRNSÝSLA}

and/or pay scales combined with increased councillor turnover prompted the Icelandic Local Government Association to suggest that an increase in remuneration would be one method of solving the problem of high councillor turnover. In relation to that, the Association published a guideline on compensation standards for local authorities (Samband íslenskra sveitarfélaga 2016). Research has shown that the return rate of councillors with a main source of income apart from remuneration is lower than the return rate for local councillors who are employed full time (Verhelst et al. 2013).

Nevertheless, there is a complex relationship between the motivation to serve publicly and intrinsic rewards, like the sense of accomplishment on the one hand and extrinsic reward, like financial remuneration on the other (Mann 2006). In relation to that, Pedersen (2014) argues that it is wise to view the motivation of councillors as being influenced by both intrinsic and extrinsic rewards. She also claims that such factors can be fairly 'self-interested' (p. 896). Findings from a study on Danish councillors—who also receive low remuneration for their council work-showed that they are also motivated by their institutional positions, and that holding these positions made them less likely to retire voluntarily (Hjelmar et al. 2010, 414). Other findings have shown that being assigned a committee or leadership position is an important factor when it comes to the possibility of re-election (Baekgaard 2014; Martin 2014).

Although there is limited research on Icelandic councils, including the career outlooks of councillors and their working conditions, there are clear indicators of substantial differences between majority and minority factions within the councils regarding responsibilities and workloads (Hlynsdóttir 2016a). In line with these findings, I expect position within the council, institutional position and seniority to be important.

\section{H1: I expect members of the council minority to be less willing to run for re-election.}

H2: I expect that holding a higher institutional position makes retirement less likely.

\section{H3: I expect that seniority makes councillors less likely to run for re-election.}

In their seminal work, Size and Democracy, Dahl and Tufte (1973) argued for a two-dimensional measurement of citizen effectiveness and system capacity. The former refers to the extent citizens can control decisions of the polity, and system capacity refers to the polity's capacity to respond effectively to its citizens. This debate is particularly relevant to research on local-level Icelandic governments, because size is a predominant theme in all local government research. In the Icelandic context, there is a great size difference between the smallest municipalities (around 50 residents) and the largest (around 120,000 residents).

From a legal perspective, the very small municipalities with few hundred residents are still supposed to deliver the same service to their citizens as is done in the capital city of Reykjavík. However, there is an enormous difference in capacity between these two types of municipalities. In most cases, smaller municipalities rely on simple administrative structures and only a handful of individuals to provide administrative services (Hlynsdóttir 2016b). Furthermore, research has shown that the population size in mu- 
nicipalities is an important factor in explaining differences in party presence (Kristinsson 2010), leadership (Hlynsdóttir 2016a), and the overall working conditions of local government authorities (Kristinsson 2001; 2014).

The number of very large municipalities is also much lower in Iceland than in neighbouring countries. What is considered large in Iceland is small in most other countries. For example, all municipalities in Denmark with less than 20,000 residents are considered 'small' (Christoffersen \& Klausen 2012). Conversely, municipalities in Iceland with more than 10,000 residents are thought to be big, and municipalities with more than 20,000 residents are simply 'huge'. Randma-Liiv (2002) has argued that public organisations in small states have more challenges in managing their public service provisions compared to those in larger states. Following this argument, the small overall nature of the Icelandic system enhances the problem of size, as the overall capacity of the system to provide support for local councillors, local administration and local leadership is diminished. This is supported by findings suggesting that increased decentralisation in recent decades has enlarged the workload for both local administrations and councils (Hlynsdóttir 2016a).

As almost all councillors in Iceland are laymen, an increase in workload affects them differently than it would if they were professionals.

H4: I expect councillors with high workloads to be less willing to run for re-election.

\section{H5: I expect council members in smaller municipalities to be less willing to run for re-election.}

The importance of the 'politics of presence' has long been established (Phillips 1995), as most research based on this approach is concentrated on the traditional question of 'where are the women' as opposed to 'which women' (Beckwith 2005). This is also related to the discussion on the presence of women as a 'critical mass' instead of as 'critical actors' (Childs \& Krook 2009). One interesting result of the Icelandic 2008 financial crisis was the development of a seemingly female-friendly atmosphere (Loftsdóttir \& Björnsdóttir 2010), this was demonstrated in the 2010 elections which resulted in a record number of female councillors. During this election, 39.8 percent of councillors were women, compared to 35.9 percent in 2006. This trend continued in the 2014 local elections, with a staggering 44 percent of the councillors being female. The number of female councillors at the local level is considerably higher than the UN benchmark of 30 percent (Alibegovic, Slijepcevic, \& Šipic 2013, 184), and in at least 20 percent of cases during the 20102014 term, the majority of councillors in individual councils were female.

It is a general belief that it is easier for women and minorities to be elected to councils in larger municipalities. Consequently, people in smaller municipalities have long been suspected of being more reserved in the number of women they elect to councillor positions (Einarsdóttir \& Hjartardóttir 2009; Kristjánsson \& Styrkársdóttir 2001; Sigurjónsdóttir \& Indriðason 2008). Thus, as the number of councils has plummeted, the number of councils with very low proportion of women or no women councillors at all has decreased. At the same time, the proportion of female councillors has risen from 21 percent in 1990 to 44 percent in 2014 (Statistics Iceland 2017b). 
Overall, empirical results show that women are underrepresented in leadership positions (Carli \& Eagly 2011; Einarsdóttir \& Hjartardóttir 2009; Johansson 2006), whether or not these posts are political or administrative in nature. For example, Duerst-Lahti $(2010,22)$ points out that the more powerful a position is expected to be, the less likely it is that a woman occupies it. It is simply much harder for women to enter into and hold leadership positions. One aspect of this problem is the concept of time and the expectation of total availability, as leaders are expected to be available full time (and all the time). As such, research findings indicate that leadership positions rely heavily on some kind of private support system from home. This is especially damaging for women (Lyon \& Woodward 2004) because they are more often responsible for the organisation of household chores.

H6: I expect women to be less willing than men to run for re-election.

\section{The Icelandic local political system}

The legal structure of the Icelandic local municipal system draws heavily from Danish tradition, as the foundation of the system at that time (established in 1872) was based on the Danish local government system (Valsson 2014). The Icelandic system is a monistic (Wollmann 2004) system, with the council legally being the most powerful entity. Local elections take place every four years (the next elections will take place in 2018) and are proportional (D'Hondt), but unlike the national elections, there is no legal threshold. The small size of the councils serves as a de facto threshold, as it is relatively difficult for new parties or lists to enter these councils. Each council has the authority to change the number of council members according to municipality size, and the change goes into effect during the next election cycle. On average, the population size represented by Icelandic local councils is 4,533 , but it drops to 2,912 when the capital city of Reykjavík is excluded (Statistics Iceland 2017a).

According to Article 11 of the Local Government Act no. 138/2011, the number of councillors should be between five and seven for municipalities with less than 2,000 residents, seven to 11 for municipalities with 2,000-9,999 residents, 11 to 15 for municipalities with 10,000-49,999 residents, 15 to 23 for municipalities with 50,000-99,999 residents and 23 to 31 for municipalities with over 100,000 residents. ${ }^{1}$ In reality, more than two-thirds of all councils consist of between five and seven-members. Icelandic councils are rather small in comparison to those in other Nordic countries. For example, the council size in rural municipalities in Norway consists of 15 to 20 members (Bjørnå 2012).

The proportional election process combined with a small number of seats make it difficult for new parties to enter the councils. It has also been argued that councils are reluctant to raise the number of council members (Kristinsson 2014), and they often use the lower end of the council member allowance limit. For example, some councils only have nine-members when they could have 15 members. However, it is often regarded as controversial if councils choose to increase the number of members, as evidenced 
in the recent news coverage of the proposed increase in number of councillors in the Reykjavík city council (RUV 2017).

When running for a council seat in the Icelandic local government elections, each party needs to set up a list of candidates that matches the number of council members in the municipality. Therefore, the party needs a list of five members for the council seats along with five substitutes (a total of ten candidates) for a five-member council. Individuals are not able to run for council seats, except in municipalities not able to use the proportional election method.

Less-populated municipalities often experience situations where no lists emerge before an election, therefore the proportional method cannot be used. When this occurs, elections are fully open, and each eligible citizen over 18 years of age (including foreigners) is a possible candidate for the council seat. Electors write the name of the candidate of their choosing on the ballot sheet, and the five people who receive the largest number of votes are legally obligated to accept a seat on the local council for the next four years. The individual receiving the highest number of votes usually becomes the leader of the council, and he or she is often the de facto manager of the municipality. This type of 'personal vote' is not very common anymore and in 2014, this was the case for 18 municipalities. In addition only one list came forward in three municipalities and its members became automatically council members, i.e. no ballot took place (Statistics Iceland 2015).

The election system is a multi-party system. However, political parties are not very strong at the local level, and local politics have a strong local presence. It may not come as a surprise that there is a strong positive correlation between the population sizes of municipalities and the emergence of political parties, since smaller communities often find it challenging to organise political work (Kristinsson 2010). Conversely, urbanisation seems to play a part in this development because voting records throughout the twentieth-century show that smaller villages and towns were much more likely to organise political work based on national parties versus their counterparts in even much larger rural communities.

In the 2014 elections, a considerable proportion of elected representatives came from local lists. Out of 184 lists, 104 were party lists affiliated with national parties and 80 were local or issue-based lists (Statistics Iceland 2015). Findings from the Kristinsson study (2001) on local government show that in municipalities with more than 2000 inhabitants, most lists were affiliated with national parties. With 120 members in local councils, the Independence Party is, by far, the best-represented party at the local level. This is followed by the Progressive Party, with 56 members. Therefore, tendency for people to organise local lists for local elections has a long tradition.

The presence of women has been growing as mentioned earlier. Forty-four percent of elected council members in 2014 were female, compared to 39.8 percent in 2010 and 35.9 percent in 2006. However, allocations for the top spot on candidate lists for Icelandic local elections are still male-dominated, as 67 percent of individuals recommended for this position are male. These numbers are similar to findings in Sweden (Statistics 


\section{STJÓRNSÝSLA}

Sweden 2013). Conversely, 58 percent of the individuals recommended for the second seat on the lists are women. Women are also more often in the third seat on a candidate list, while numbers for the fourth and fifth seat show an equal gender distribution (Statistics Iceland 2010; 2015).

Furthermore, 58 percent of council members elected in 2014 were new recruits. Of the council members that were elected in 2010 and who returned to the council four years later, 46 percent were male and 37 percent were female. These numbers are similar to what was revealed in the 2010 elections (Statistics Iceland 2010; 2015).

As mentioned earlier, the main decision-making body is the council, and it appoints committees that are each functionally responsible for a defined area. The committees mirror the relative political strength of different parties or lists; however, committee members do not need to be council members. It is likely that committees that closely match party affiliations are more common in larger municipalities, but members are also often chosen because of alleged expertise. Suspicion of gender biases in relation to committees has risen, as more men are supposedly appointed to technical committees, while more women are appointed to social service and educational committees (Jóhannsdóttir 2010).

The executive committee/board has a special status, as it is only found in municipalities with councils consisting of seven or more members. Membership on this committee/board directly reflects the majority/minority combination in the council, and its members are always elected council members. For example, when the board consists of three individuals, two represent the majority in the council and one represents the minority, regardless of how many total parties are represented in the council. Thus, not all parties have a representative on the executive board. In recent years, the executive committee has been gaining political importance at the council's expense (Hlynsdóttir 2016a), and it has become more common for individuals to invest more political leadership in the role of executive board leader versus the role of council leader.

Similar to the national level, coalitions have been a central part of Icelandic local government. This is especially true in larger councils. However, due to the number of very small councils (five members), the most common type of council majority during the 2010-2014 term was a one-party majority. During that term, 46 percent of all councils were run by a one-party majority. It was also normal for only two lists to be present in less-populated municipalities. Other councils had two, three or even four party majorities. As is the case for the national government, minority leadership is exceedingly rare. Consequently, the high number of councils with only five or seven seats produces a clear majority system, as most councils (around 65 percent) have either one or two-party majorities. The role of political leadership is invested in the council leader, executive board leader or an executive mayor (see Hlynsdóttir 2016b for further discussion), but these political leaders do not have any decision-making powers apart from the council with the exception of the executive mayor. Nevertheless, norms and practices give them great power (Hlynsdóttir 2016a).

Compared to other countries, Icelandic local authorities enjoy a high level of au- 
tonomy (Ladner, Keuffer, \& Baldersheim 2015), as their right to local self-governance is clearly stated in Article 78 of the Icelandic constitution. Similar to the local authorities in other Nordic countries (and unlike English local authorities), Icelandic local authorities are able to take on any task they choose as long as it is not legally assigned to any other body. However, Icelandic local authorities do not have the power to levy taxes. Until recently, local authorities also played only a limited role in the provision of the welfare service, which contributed to a tradition of entrepreneurship (Kristinsson 2015) within local councils.

Different from their Nordic counterparts, Icelandic local council members are unusually active in the development and implementation of tasks (Hlynsdóttir 2016a; Kristinsson 2014). In the neighbouring countries, the councils often function as assemblies. In contrast, the Icelandic local councils are relatively small, so they have a much more functional and active role in the day-to-day management of the municipality. Most mid-sized local authorities rely on just 10 to 15 people within their core administration (Hlynsdóttir 2016a), and many municipalities with less than 1,000 residents have an even smaller number of people working within their core administration. As a result, the level of professional skills is relatively low within the administration, and local authorities rely heavily on external actors like private law firms, the main office of the Local Government Association, or staffs within other inter-municipal cooperation schemes. Therefore, it is reasonable to assert that council members are an important extension of the local administration.

With the exception of the Reykjavík city council, which employs its city council members full-time, other council members are paid part-time for their services. Council leaders or executive leaders are often full-time, while other council members are paid by the hour or per meeting. Article 32 in Local Government Act, no. 138/2011 states that council members should be compensated. However, it does not specify the manner of how members are to be compensated. The below survey reveals a complex system of monthly payments; some are paid by the hour, some are paid by meetings and some payments are attached to the Parliamentarian salaries. There was no clear pattern. Kristinsson (2014) has pointed out that councillors with a low level of compensation are less satisfied with their work conditions than those with higher levels of compensation.

\section{Data}

Data were collected from April 2017 to June 2017. The questionnaire was based on a survey originally used in the Municipal Assemblies in European Local Government (MAELG) project (Egner, Sweeting, \& Klok 2013). The survey was sent via email to all councillors (504) who were active during the data collection period. The response consisted of 300 councillors (59.9 percent), with 54 percent of the respondents being male and 46 percent being female. The sample was representative of the population, with 64 percent of all female councillors and 57 percent of all male councillors responding to the survey.

In this research, the dependent variable is the councillors' willingness to run for re- 


\section{STJÓRNSÝSLA}

election. This was measured by the question: 'Now the end of this term is approaching. Would you like to run for council again?' Responses were: 'Yes, I would like to continue as councillor' (29.9 percent), 'No, I plan to quit as councillor' (43.45 percent) and 'Undecided' (26.8 percent). Responses rated as 'undecided' were left out of the final analysis. Indications of the councillors' willingness to run for re-election were explored through the following questions:

- How much time per month do you spend on the following activities? (Council and committee meetings, meeting with party, desk work preparation preparing your activity in the council, meetings with citizens and other important activity as councillor).

- Do you presently hold any of the following elective or executive offices? (Council leader/leader of executive committee/ executive mayor/ minority leader/leader of a committee).

- For how many years have you been a councillor in total? This variable as also used as an interval variable, grouped into five groups of council terms from one council term to five or more.

- Considering your responsibilities, do you think your allowance as councillor is adequate or not? (1-7) $1=$ Not adequate; $7=\mathrm{Ad}$ equate.

- Is your party in majority or minority in the council? (majority, minority, personal vote).

- How much time do you spend on the following activities per week? (Paid employment; unpaid care and household work).

Other variables that were adjusted were the population size of councillors' municipalities $^{2}$ and the age and gender of the respondents. As seen in Table 1 proportion of responses between different population groups were relatively similar. Furthermore, the response rate within each group was representative of the population with around 60 percent, which is similar to the overall response rate. The mean age of the respondents was 49.4 years.

Table 1. Population size, proportion, and councillors mean age

\begin{tabular}{lrcc}
\hline Population & $\%$ & Mean age & SD \\
\hline$<200$ & 8.7 & 54.1 & 10.4 \\
$200-499$ & 15.0 & 48.7 & 9.7 \\
$500-999$ & 18.0 & 48.5 & 9.5 \\
$1000-1999$ & 17.7 & 47.6 & 7.6 \\
$2000-4999$ & 18.7 & 49.3 & 8.2 \\
$5000-9999$ & 7.0 & 50.5 & 7.6 \\
$10000>$ & 15.0 & 50.6 & 8.1 \\
\hline Total & 100 & 49.4 & 8.8 \\
\hline
\end{tabular}




\section{Results}

Holding an institutional position has been shown to be a decisive factor for councillors when it comes to choosing whether to stay or leave the council (Hjelmar et al. 2010). Seniority (measured by the number of years in the council or in number of terms) is also an important factor, because people generally tend to move higher up the institutional ladder the longer they stay in the council. Previous research findings indicate that an important indicator for holding a higher institutional position is being a majority member in the council (H1) (Hlynsdóttir 2016a).

Figure 1. The willingness of councillors to continue or quit

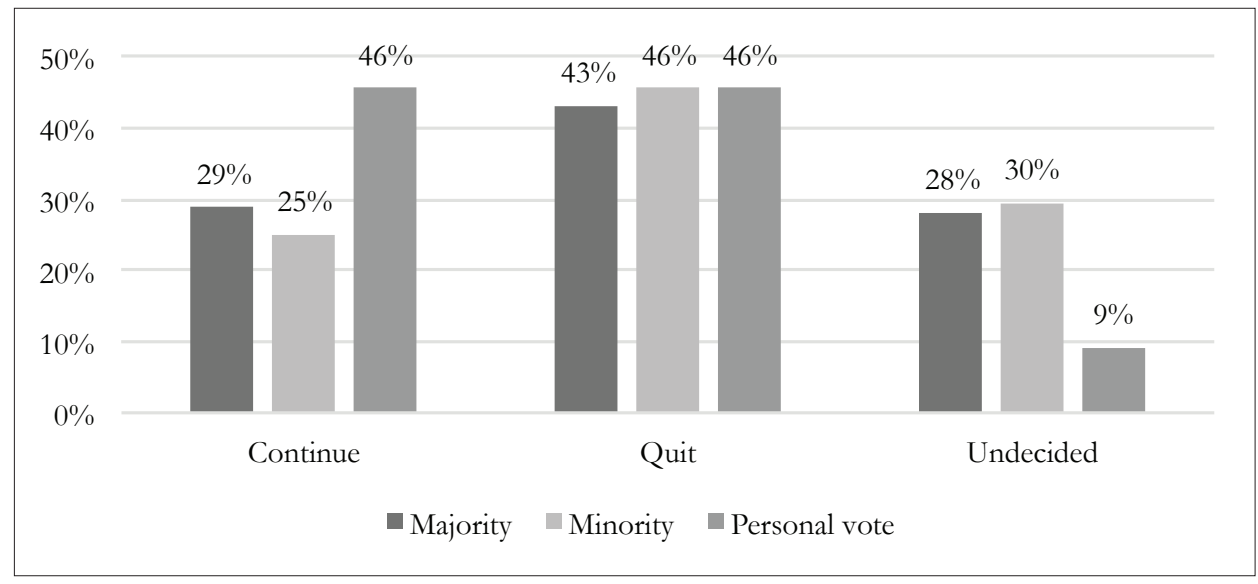

Although members of the minority are generally believed to be less influential in the context of Icelandic councils, there is no statistically significant difference between members of the majority or minority when it comes to deciding if they would like to run for council again. Interestingly, council members elected through 'personal votes' have a much lower percentage of undecided responses (9 percent) (Fig 1). The practice of personal voting is mostly used in very small municipalities that have a small pool of possible candidates. This correlation also exists when considering the average time spent as a council member. The average time of service in the council is 6.48 years for members of the majority and 6.36 years for minority members. However, councillors voted in through personal votes have spent an average of 8.45 years as council members.

Danish findings demonstrate that council members with high seniority are more likely to quit than the more junior members of the councils. This is partly age-related and partly related to the reality that the possibility of advancement to higher positions of power or prestige is limited at the local level. Thus, those who have reached the limit of advancement tend to leave (Hjelmar et al. 2010). Therefore, seniority is expected to have a negative influence on councillors' willingness to stay in the council (H2).

The results show that there is a statistically significant difference $(\mathrm{t}(208),=3.07 \mathrm{P}<$ 0.01 ) between those who would like to run again for council and those who would not. 
However, unlike the Danish findings, seniority makes councillors more willing to stay on as council members. Those who are willing to run for council again have already been councillors for an average of 7.62 years $(S D=6.98)$. Those who are not willing to run again have served an average of 5.23 years in the council $(S D=4.26)$.

Figure 2. Proportion of councillors and number of council terms

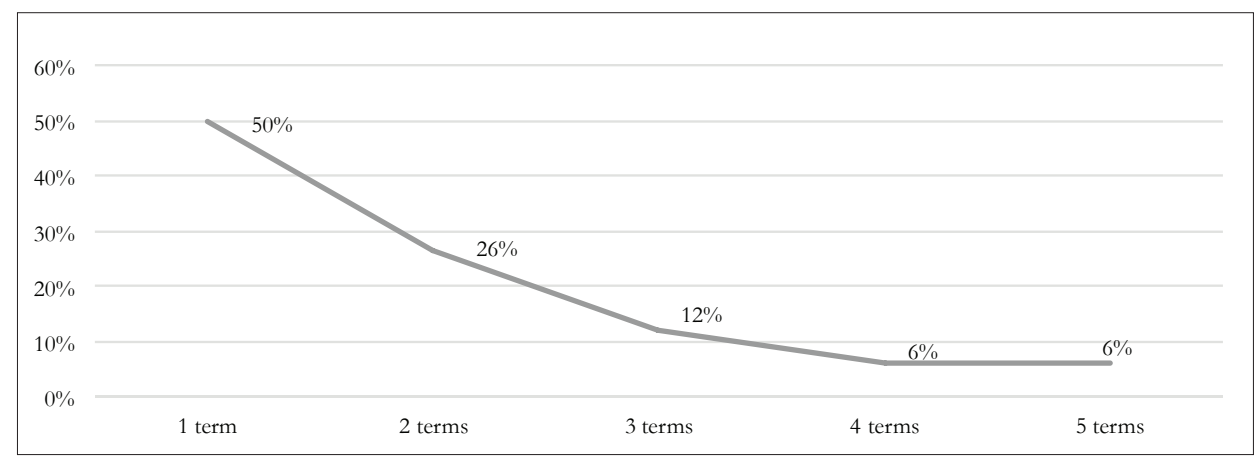

The proportion of council members in relation to the number of terms served, showed that around half of all council members in the survey are in their first term (49.7 percent). Seventy-six percent of the respondents are in their first two terms. Overall, Icelandic councillors tend to be slightly younger than their average European counterparts. The mean age of Icelandic local councillors in 2014 was 45.8 years (Statistics Iceland 2015), compared to 51.1 years in the MAELG study (Reynaert 2012). More than 40 percent of the respondents in this survey belonged to the 40 to 49 age group. In contrast, the Danish findings showed that only 18 percent of councillors were in this age group, and 40 percent of the respondents were councillors 60 years of age or older (Hjelmar et al. 2010). This suggests that age does not contribute to councillors' voluntary retirement decisions.

\section{Figure 3. Trend in gender proportions and number of election terms}

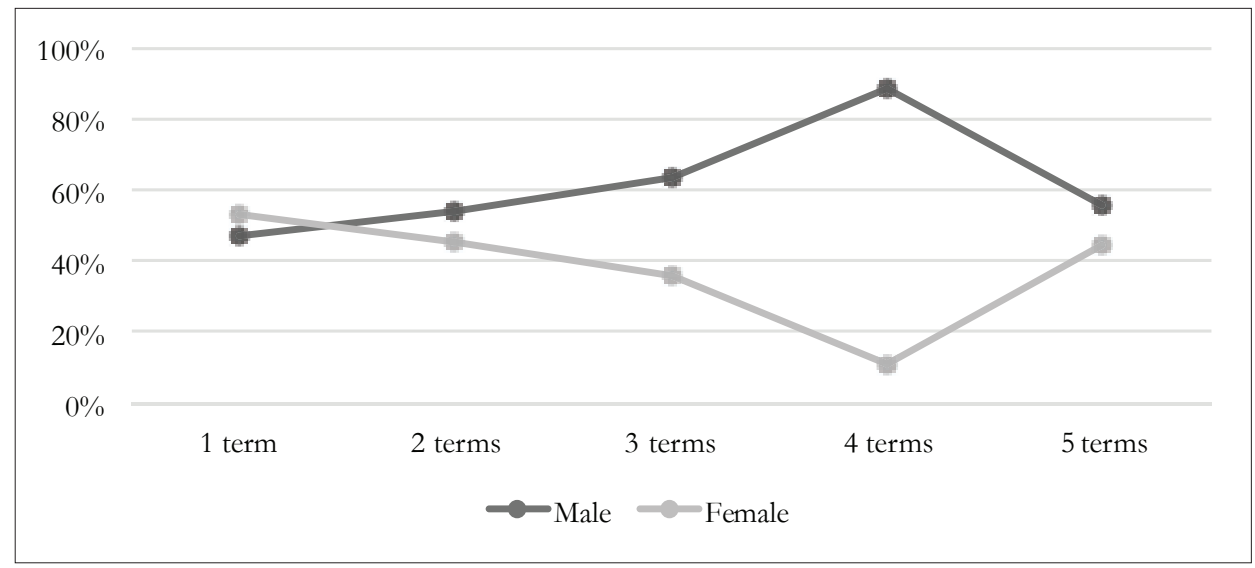


A comparison of female and male council members shows that there is a statistically significant difference in the number of years served in the council. On average, as female councillors $(\mathrm{M}=5.6, \mathrm{SD}=4.6)$ serve for a much shorter period than male councillors $(\mathrm{M}=7.5, \mathrm{SD}=6.4)(\mathrm{t}(297)=3.037(<0.003))$. When adjusting for the number of terms served, no significant difference was found. However, there is a notable and proportional difference in the willingness of male and female councillors to continue as council members (Fig 3). Of the women who decided to continue as council members, two-thirds are in their first term, while only 12.5 percent of women in their second term decided to continue as council members. When compared to their female counterparts, 56.5 percent of male councillors in their first term decided to continue as council members, 23.9 percent of male councillors who decided to continue are in their second term.

A similar trend arises when looking at those who decided not to run for council again. Of the female councillors who decided to leave, 46.9 percent are in their first term and 35.9 percent are in their second term. Of the males who decided to leave, 37.7 percent are in their first term and 26.2 percent are in their second term. For all female councillors who decided to leave, 82.8 percent are in their first two terms. For all male councillors who decided to leave, 63.9 percent are in their first two terms. Both female and male council members are more likely to leave after their first term in the council. However, a much higher proportion of women leave after the first and the second term compared to their male counterparts.

Research findings suggest that institutional position plays an important role when it comes voluntary retirement. Therefore, it was hypothesized that holding an institutional position was related to councillors' willingness to run for council again (H2). Results showed that holding a higher institutional position was not significantly related to the

Figure 4. Institutional position and gender

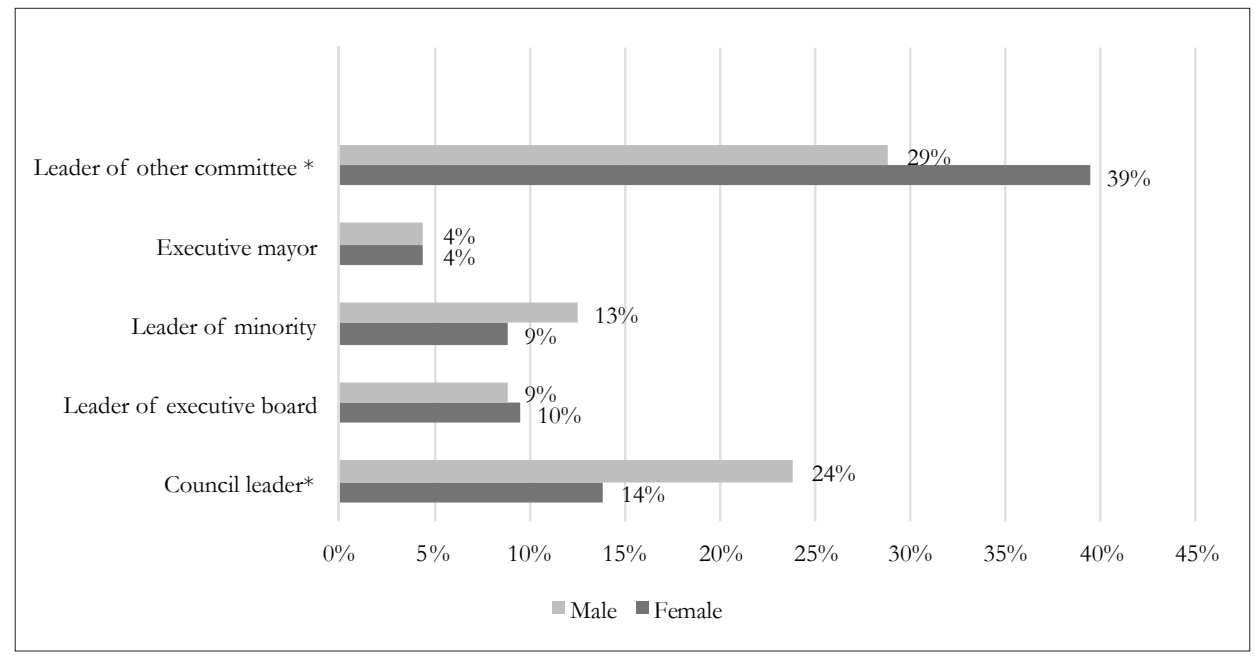

$* \mathrm{P}<0.05$ 


\section{STJÓRNSÝSLA}

councillors' decision to not run for council again. This is interesting, as an institutional position is usually seen as motivation for councillors to remain (Hjelmar et al. 2010).

The findings from the survey further reveal that 60 percent of all respondents are leading some kind of committee. Consequently, the possibilities for councillors to take on responsibilities through committee leadership are considerable. However, notable findings were exposed when looking closer at institutional positions in relation to gender (see Fig 4).

When exploring higher institutional positions in comparison to lower level institutional positions the findings reveal a significant gender difference. This suggests a tendency towards gender-based division of labour within local councils (Fox \& Schuhmann 1999; Kreimer 2004). There, seems to be an abundance of possibilities for council members to take on responsibilities through leadership of a committee, albeit gendered possibilities. The number of individuals holding such posts also suggests a large workload on council members. These council members are usually referred to as 'backbenchers'.

Workload is an important factor when looking at council work. Usually, this is also a defining difference between a system based on the laymen principle and a system based on council work as a profession (Mouritzen \& Svara 2002). Another issue is remuneration, as there has been an ongoing debate in Iceland regarding how much local councillors should be compensated for their council work (Helgason 2017). In relation to this, I hypothesized that councillors with a larger workload were less willing to run for council again (H4). I also hypothesized that population size is negatively related to councillors' willingness to run again (H5). This suggests that councillors in small municipalities are more likely to plan a voluntarily retirement than councillors in larger municipalities.

Findings from the MAELG survey show that there is a great variation between countries regarding the hours spent on council work (Aars, Offerdal, \& Rysavy 2012). The mean hours spent on council work each month range from 13.1 in Croatia to 57.1 in Spain. Of the Nordic countries represented in the study, Swedish councillors spent on average of 17.8 hours each month on council work and Norwegian councillors spent an average of 18.8 hours each month on council work. Conversely, a Danish study showed that Danish councillors worked 19 to 20 hours each week on council-related work (Dahlgaard, Hjelmar, Olsen, \& Pedersen 2009). This suggests that Danish councillors spend a staggering 76 to 80 hours each month on council work. As a matter or note, the Danish system relies on the laymen system, and the local councillors receive only limited remuneration for their work. In an Icelandic study on local councillors in municipalities with 2,000 residents or more, findings showed that councillors in larger municipalities worked more on council-related work than councillors in smaller municipalities (Kristinsson 2014).

Findings from the study show that the average Icelandic councillor spends 40.9 hours a month on council-related work. This is obviously much higher than most other European countries, including our Nordic neighbours, with the exception of Denmark. As is evident in Table 2, there is a considerable difference in the workload between different size groups. Council members in municipalities with less than 500 residents work the lowest number of hours each month. 
Table 2. Population size and hours spent by councillors on council work

\begin{tabular}{lccc}
\hline Population size & $\begin{array}{c}\text { Hours spent on council work each month } \\
\text { Mean }\end{array}$ & N & SD \\
\hline$<200$ & 22.7 & 24 & 25.6 \\
$200-499$ & 25.9 & 43 & 18.2 \\
$500-999$ & 34.7 & 47 & 41.3 \\
$1000-1999$ & 31.8 & 49 & 34.8 \\
$2000-4999$ & 41.5 & 51 & 38.2 \\
$5000-9999$ & 41.1 & 21 & 14.4 \\
$10000>$ & 81.6 & 44 & 49.1 \\
\hline Total & 40.9 & 279 & 39.2 \\
\hline P $<001$ & & &
\end{tabular}

In relation to the workload and the willingness of council members to continue in the council, those who were willing to run again worked more hours on average ( $\mathrm{M}=$ $45.8, \mathrm{SD}=44.6)$ than those who were not willing to run for council again $(\mathrm{M}=35.2$, $\mathrm{SD}=27.9)$. The mean difference $(\mathrm{t}(197)=-2.25, \mathrm{P}<0$.) is statistically significant. Thus, the workload is positively correlated with the councillors' willingness to run for council again, not negatively, as was expected (H4). However, care must be taken when interpreting these findings, as they do not necessarily suggest that increasing the councillors' workload will lower the rate of voluntary retirements. Overall, local councillors spend a considerable time of their 'leisure' time doing council work. Previous research findings showed considerably more time being spent on council work (Kristinsson 2014) than the findings from this survey.

Another important factor when it comes to interpreting workload is the size of the local authority. The survey results support the importance of size in relation to council members' willingness to continue as council members. Therefore, those willing to run for council again are more likely to come from more populated municipalities $(\mathrm{M}=4.53$, $\mathrm{SD}=2)$ than less populated municipalities $(\mathrm{M}=3.64, \mathrm{SD}=1.75)(\mathrm{t}(209)=-3.44, \mathrm{P}<$ $0.001)$.

In relation to this, the council members' satisfaction with remuneration was also explored. A similar trend was noticed in relation to the population size and satisfaction with remuneration groups. Apart from a very small population group of less than 200 residents, satisfaction with remuneration gradually rose with population size. This trend was further strengthened when satisfaction with payments was compared to willingness to run for council again. Satisfaction with payments for council work was higher (on average) among those who intended to run again for council $(\mathrm{M}=4.26, \mathrm{SD}=1.62)$ than among those who intended to leave $(\mathrm{M}=3.26, \mathrm{SD}=1.71)$. The mean difference ( $\mathrm{t}(209)$ $=-3.38, \mathrm{P}<0.01)$ is statistically significant. These findings support the hypothesis that councillors from smaller municipalities are more likely to opt for voluntary retirement than councillors from larger municipalities (H5).

Studies on local government have shown that there is a considerably higher turnover 
of councillors in systems based on the laymen principle (Steyvers \& Verhelst 2012). In addition, small municipalities (anything below 10,000 residents) have a lower level of administrative capacity, both in manpower and professional capacity (Hlynsdóttir 2016a). Thus, council members in large municipalities have better administrative support systems and are more often partly or fully compensated for their council work. This decreases the likelihood of voluntary retirement.

The final issue is gender. At the beginning of this discussion, a hypothesis was put forward regarding women being less willing than men to run for council again. Although proportionally more women than men plan to leave the council, no statistically significant difference between female and male councillors in relation to voluntary retirement was found.

However, when looking at the working conditions of both genders, notable differences become known (see Table 3).

Table 3. Gendered differences in hours worked in the council and for paid and unpaid work

\begin{tabular}{lcccccc}
\hline & \multicolumn{2}{c}{ Female } & \multicolumn{2}{c}{ Male } & & \\
& M & SD & M & SD & t-test & Df \\
\hline Hours worked in council (month) & 37.3 & 33.6 & 44 & 44.5 & 1.42 & 277 \\
Hours worked in payed profession (week) & 42 & 11.8 & 46,7 & 13.1 & $-2.88^{* *}$ & 233 \\
Hours worked for unpaid work (week) & 24.8 & 11.1 & 16.9 & 13.1 & $-3.25^{* *}$ & 165 \\
\hline
\end{tabular}

$\mathrm{P}<.001$

As shown in Table 3 there is no statistically significant difference between genders regarding the number of hours spent on council work. However, a whole new pattern is revealed when it comes to work outside the council. The average work-week for females is shorter than the average work-week for males. However, women spend more time each week on unpaid work than their male counterparts. This supports other findings that claim women are more often responsible for unpaid housework (Lyon \& Woodward 2004), making time an important variable when it comes to the working conditions for female councillors. This is further confirmed by the fact that the 44.4 percent of female councillors who opted for voluntary retirement agreed with the statement 'I think political work is too time-consuming in relation to family or occupation'. Only 29.5 percent of males agreed with this statement.

\section{Conclusions}

This paper set out to explore the differences between Icelandic councillors who are planning voluntary retirement from the council and those who are not. The findings reveal a trend of high workloads, high voluntary turnover, and gendered differences in working conditions within the council. The findings also reveal statistically significant differences between councillors' work conditions based on the population size of the local authority. 
What difference does it make if there is a high level of voluntary retirement in councils? One might suggest that it is a sign of healthy democracy to have a high turnover in councils, as it makes it possible for more citizens to participate in local politics and it increases the likelihood of the council being representative of its population (Aars \& Offerdal 1998). Conversely, a high turnover rate may pose a problem. Most local authorities have a relatively small local administration; and the council plays an important role in the process of task implementation alongside the municipal manager. Therefore, a high level of turnover in the council, combined with a high level of turnover among municipal administrators (Hlynsdóttir 2016c) and a small administration, poses a threat to the overall performance of the local level of government.

Based on the findings, one solution is to amalgamate, as local councillors in larger municipalities seem to be more satisfied with their work conditions. However, care must be taken when drawing such conclusions. A Danish study on councillors' working conditions showed (Dahlgaard et al. 2009) that the councillors' workload actually increased after the last wave of amalgamation in Denmark. Furthermore, the Danish system has one of the largest local authorities in Europe, as well as the largest number of tasks. In that system, there are reports of extreme workloads on local council members.

Accordingly, any major changes to the structure of Icelandic local authorities in regard to population size are likely to have great effects on local councillors and their workloads. Thus, having larger local authorities will mean larger workloads. It will also mean more demands for remuneration on the councillors' behalf. This trend is already visible in the largest municipalities. This would signify a change from the tradition of viewing councillors as laymen to regarding them as professionals. The question remains: how will that affect local democracy?

\section{Acknowledgements}

The author is grateful to the University of Iceland Research Fund for a grant rewarded to the survey this paper is based on.

\section{Notes}

1 In regard to the city of Reykjavík, the decions of increasing the number of city council members was postponed. The city council has now decided to increase the number of city council members before the next local election in 2018.

2 Municipalities were divided into seven population groups <200 (1), 200-499 (2), 500-999 (3), 10001999 (4), 2000-4999 (5), 5000-9999 (6), 10000> (7).

\section{References}

Aars, J., and Offerdal, A. (1998). 'Local Political Recruitment in Crisis? A Comparison of Finland and Norway', Scandinavian Political Studies 21(3), 207-230. http://doi.org/10.1111/j.1467-9477.1998. tb00013.x

Aars, J., Offerdal, A., and Rysavy, D. (2012). 'The Careers of European Local Councillors: A Cross-National Comparison', Lex Localis-Journal of Local Self-Government 10(1), 63-84. Retrieved from http:/ / pub.lex-localis.info/index.php/LexLocalis/issue/view/63 


\section{STJÓRNSÝSLA}

Alibegovic, D.J., Slijepcevic, S., and Šipic, J. (2013). 'The Gender Gap among Local Representatives: A Potential for Local Development?' in B. Egner, D. Sweeting, and P.-J. Klok (eds.), Local Councillors in Europe (pp. 181-202). Wiesbaden: Springer VS.

Baekgaard, M. (2014). 'Within-party Allocation of Committee Seats: Evidence from Danish Local Elections.' Scandinavian Political Studies 37(4), 385-405. http://doi.org/10.1111/1467-9477.12026

Beckwith, K. (2005). ‘A Common Language of Gender?’ Politics \& Gender 1(1), 128-138. http://doi. org/10.1017/S1743923X05211017

Beetham, D. (1996). 'Theorising Democracy and Local Government', in D. King and G. Stoker (eds.), Rethinking local democracy (pp. 28-48). Basingstoke: Palgrave Macmillan.

Bjørnå, H. (2012). 'Gender Balance and Institutions in Local Government - Examples from Rural Norway' Lex Localis-Journal of Local Self-Government 10(2), 129-152. http://doi.org/10.4335/10.2.129152(2012)ISSN

Borraz, O., and John, P. (2004). 'The Transformation of Urban Political Leadership in Western Europe', International Journal of Urban and Regional Research 28(March), 107-120.

Carli, L.L., and Eagly, A.H. (2011). 'Gender and Leadership', in A. Bryman, D. Collinson, K. Grint, B. Jackson, and M. Uhl-Bien (eds.), The Sage Handbook of Leadership (pp. 103-117). Los Angeles: Sage Publications.

Childs, S., and Krook, M.L. (2009). 'Analysing Women's Substantive Representation: From Critical Mass to Critical Actors', Government and Opposition 44(2), 125-145. http://doi.org/10.1111/j.14777053.2009.01279.x

Christoffersen, H., and Klausen, K.K. (2012). Den danske kommunekonstruktion: Kommunedannelse med og efter strukturreformen: professionalisering, organisering og performance. Odense: Syddansk Universitetsforlag.

Dahl, R.A., and Tufte, E.R. (1973). Size and Democracy. Stanford: Stanford University Press.

Dahlgaard, J.O., Hjelmar, U., Olsen, A., and Pedersen, L.H. (2009). Kommunalpolitikeres rolle og råderum. AKF Working paper. AKF, Anvendt KommunalForskning. Retrieved from https://www.kora.dk/ media/272061/udgivelser_2009_pdf_kommunalpolitikeres_rolle_og_raaderum.pdf

Demir, T. (2009). 'Politics and Administration: Three Schools, Three Approaches, and Three Suggestions', Administrative Theory \& Praxis 31(4), 503-532.

Duerst-Lahti, G. (2010). 'The Consequences of Gender for for Women's Political Leadership', in K. O'Connor (ed.), Gender and Women's Leadership: A Reference Handbook. Volume one (pp. 20-30). California: Sage Publications.

Egner, B., Sweeting, D., and Klok, P.-J. (2013). Local Councillors in Europe. Wiesbaden: Springer VS.

Einarsdóttir, P., and Hjartardóttir, G.L. (2009). 'Gender Bias in Politics. Changes and Factors of Influence', Icelandic Review of Politics \& Administration 5(1), 5. http://doi.org/10.13177/irpa.a.2009.5.1.1

Fox, R.L., and Schuhmann, R.A. (1999). 'Gender and Local Government: A Comparison of Women and Men City Managers', Public Administration Review 59(3), 231-242. Retrieved from http:// web.a.ebscohost.com/ehost/pdfviewer/pdfviewer?sid=1604b797-3fd4-45d3-a87a-7642a525105a $\% 40$ sessionmgr4004\&vid=1\&hid $=4212$

Frederickson, G.H., and Smith, K.B. (2003). The Public Administration: Theory Primer. Westview Press.

Guérin, É., and Kerrouche, É. (2008). 'From Amateurs to Professionals: The Changing Face of Local Elected Representatives in Europe', Local Government Studies 34(2), 179-201. http://doi. org $/ 10.1080 / 03003930701852260$

Helgason, P. (2017). 'Sveitarstjórnarmenn taka sér gríðarlega launahækkun', Stundin 3(15), 14-16.

Hjelmar, U., Olsen, A.L., and Pedersen, L.H. (2010). 'Should I Stay or Should I Go Now? Voluntary Retirement from Danish Local Government', Scandinavian Political Studies 33(4), 402-416. http:/ / doi.org/10.1111/j.1467-9477.2010.00257.x

Hlynsdóttir, E.M. (2016a). 'Administrative capacity and long-term policy making at the Icelandic local level', Icelandic Review of Politics \& Administration 12(2), 237-258. http://doi.org/10.13177/ irpa.a.2016.12.2.3 
Hlynsdóttir, E.M. (2016b). 'Leading the locality: Icelandic local government leadership dilemma', Lex Localis 14(4), 807-826. http://doi.org/10.4335/14.4.807-826(2016)

Hlynsdóttir, E.M. (2016c). 'Professionalism among Icelandic Mayors: Job Postings, Experience and Education as Determinants of Professionalism at the Icelandic Local Level', Icelandic Review of Politics \& Administration 12(1), 1. http://doi.org/10.13177/irpa.a.2016.12.1.1

Jóhannsdóttir, Á. (2010). Konur og karlar i nefndum: „Við eigum å velja hafasta fólkið“. MA thesis University of Iceland.

Johansson, V. (2006). 'Gendered Roads to Mayorship in Different Welfare States', in H. Bäck, H. Heinelt, and A. Magnier (eds.), The European Mayor: Political Leaders in the Changing Context of Local Democracy (pp. 99-122). Wiesbaden: VS Verlag für Sozialwissenschaften.

Kreimer, M. (2004). 'Labour Market Segregation and the Gender-Based Division of Labour', European Journal of Women's Studies 11(2), 223-246. http://doi.org/10.1177/1350506804042097

Kristinsson, G.H. (2001). Staðbundin stjórnmál: Markmið og árangur sveitarfélaga. Reykjavík: Háskólaútgáfan.

Kristinsson, G.H. (2010). 'The greatest number of party members? Membership structures in Icelandic political parties', Icelandic Review of Politics \& Administration 6(2), 123-150. http://doi.org/10.13177/ irpa.a.2010.6.2.1

Kristinsson, G.H. (2014). Hin mörgu andlit lýdrađis: Pátttaka og vald á sveitarstjórnarstiginu. Reykjavík: Háskólaútgáfan.

Kristinsson, G.H. (2015). 'Political control and perceptions of corruption in Icelandic local government', Icelandic Review of Politics \& Administration 11(1), 1-18. http://doi.org/10.13177/irpa.a.2015.11.1.1

Kristjánsson, S., and Styrkársdóttir, A. (2001). Konur, flokkar og frambod. Reykjavík: Háskólaútgáfan.

Ladner, A., Keuffer, N., and Baldersheim, H. (2015). Local Autonomy Index for European countries (19902014). Release 1.0. Brussels: European Commission.

Lepine, E., and Sullivan, H. (2010). 'Realising the Public Person', Local Government Studies 36(1), 91-107. http://doi.org/10.1080/03003930903445673

Local Government Act no 138/2011.

Loftsdóttir, K., and Björnsdóttir, H. (2015).'Áhættusækni í útrásargleði: Karlar og konur í bönkum og fjármálafyrirtækjum' Icelandic Review of Politics and Administration 11(2), 231-246.

Lyon, D., and Woodward, A.E. (2004). 'Gender and Time at the Top: Cultural Constructions of Time in High-Level Careers and Homes', European Journal of Women's Studies 11(2), 205-221. http://doi. org/10.1177/1350506804042096

MacKenzie, S.A., and Kousser, T. (2014). 'Legislative Careers', in S. Martin, T. Saalfeld, and K.W. Strøm (eds.), The Oxford Handbook of Legislative Studies (pp. 286-310). Oxford: Oxford University Press. http://doi.org/10.1093/oxfordhb/9780199653010.013.0013

Mann, G.A. (2006). 'A Motive to Serve: Public Service Motivation in Human Resource Management and the Role of PSM in the Nonprofit Sector', Public Personnel Management 35(1), 33-48. http://doi. org $/ 10.1177 / 009102600603500103$

Martin, S. (2014). 'Committees', in S. Martin, T. Saalfeld, and K.W. Strøm (eds.), Oxford Handbook of Legislative Studies (pp. 352-368). Oxford: Oxford University Press.

Mouritzen, P.E., and Svara, J.H. (2002). Leadership at the Apex: Politicians and Administrators in Western Local Governments. Pittsburgh: Pittsburgh University Press.

Norris, P. (1997). 'Introduction: Theory of Recruitmentð, in P. Norris (ed.), Passages to Power: Legislative Recruitment in Advanced Democracies (pp. 1-14). Cambridge: Cambridge University Press.

Pedersen, L.H. (2014). 'Committed to the Public Interest? Motivation and Behavioural Outcomes among Local Councillors' Public Administration 92(4), 886-901. http://doi.org/10.1111/j.14679299.2012.02107.x

Phillips, A. (1995). The Politics of Presence. Oxford: Oxford University Press.

Randma-Liiv, T. (2002). 'Small states and Bureaucracy: Challenges for Public Administration', Trames, 6(4), 374-389. 


\section{STJÓRNSÝSLA}

Reynaert, H. (2012). 'The Social Base of Political Recruitment. A Comparative Study of Local Councillors in Europe', Lex Localis-Journal of Local Self-Government 10(1), 19-36. http://doi. org/10.4335/10.1.19-36(2012)

RUV. (2017, September 19). 'Borgarfulltrúum fjölgar í 23'. Retrieved from http://ruv.is/frett/fjolgunborgarfulltrua-verdi-endurskodud

Samband íslenskra sveitarfélaga. (2013). Umsögn um fru. til laga um sveitarstjórnarkosningar (persónukjör), 537. mál. Retrieved from http://www.samband.is/media/umsagnir-141/Sveitarstjornarkosningar.pdf

Samband íslenskra sveitarfélaga. (2016). Vidmidunarlaunatafla fyrir fulltrúa i sveitarstjórnum. Reykjavík. Retrieved from https://ibuagatt.akranes.is/meetingsearch/displaydocument.aspx?itemid=30636 028793268816250\&meetingid=1607001F\&filename=Erindi og viðmiðunarlaunatafla júní 2016. pdf\&cc $=$ Document

Schlesinger, J.A. (1966). Ambition and Politics. Political Careers in the United States. Chicago: Rand McNally \& Company.

Sigurjónsdóttir, Á.J., and Indriðason, I.H. (2008). 'Supply or demand? Women's success in party primaries', Icelandic Review of Politics \& Administration 4(2), 205-230. http://doi.org/10.13177/ irpa.a.2008.4.2.5

Statistics Iceland. (2010). 'Local Government Elections 29 May 2010’, Hagtídindi, (May), 1-48. Retrieved from https://hagstofa.is/lisalib/getfile.aspx?ItemID=11577

Statistics Iceland. (2015). 'Local Government Elections 31 May 2014', Hagtíðindi, (November), 1-48. Retrieved from file:///C:/Users/eva/Downloads/download (5).pdf

Statistics Iceland. (2017a). Mannfjöldi eftir kyni, aldri og sveitarfélögum 1998-2017 - Sveitarfélagaskipan hvers árs. Retrieved from http://px.hagstofa.is/pxis/pxweb/is/Ibuar/Ibuar_mannfjoldi_2_ byggdir_sveitarfelog/MAN02001.px/?rxid=0245a5b1-8f73-49a4-bdd9-b3a83886f5b3

Statistics Iceland. (2017b). Sveitarstjórnarkosningar - Lykiltölur 1962-2014. Retrieved from http:// px.hagstofa.is/pxis/pxweb/is/Ibuar/Ibuar_kosningar_sveitastjorn_svf_yfirlit/KOS03101.px

Statistics Sweden. (2013). Elected Representatives in Municipal Councils - A study of how they view their terms in office. Retrieved from https://www.scb.se/statistik/_publikationer/ME0107_2013A01_BR_ME09BR1301 .pdf

Steyvers, K., and Verhelst, T. (2012). 'Between Layman and Professional? Political Recruitment and Career Development of Local Councillors in a Comparative Perspective', Lex Localis-Journal of Local Self-Government 10(1), 1-17. http://doi.org/10.4335/10.1.1-17(2012)

Valsson, T. F. (2014). Sveitarstjórnarréttur. Reykjavík: Codex.

Verhelst, T., Reynaert, H., and Steyvers, K. (2013). 'Political Recruitment and Career Development of Local Councillors in Europe', in B. Egner, D. Sweeting, and P.-J. Klok (eds.), Local Councillors in Europe (pp. 27-50). Wiesbaden: Springer Vs.

Wollmann, H. (2004). 'Urban Leadership in German Local Politics : The Rise, Role and Performance of the Directly Elected (Chief Executive) Mayor', International Journal of Urban and Regional Research 28(March), 150-165. 